\title{
シクラメンうどんこ病（新称）の発生
}

\section{萩原＼cjkstart廣*・我孫子和雄*・井＼cjkstart智史*・清水 時哉**・小木曾秀紀**}

\author{
Hiroshi Hagiwara*, Kazuo Abiko*, Satoshi Izutsu*, Tokiya Shimizu** \\ and Hideki OGISO** : Powdery Mildew of Cyclamen \\ (Cyclamen persicum) in Japan
}

\begin{abstract}
In November 1997 powdery mildew of cyclamen was found in Nagano prefecture, Japan. White, powdery mycelial colonies appeared on petals. Artificial inoculation with the fungus was successful on cyclamen petals, but not on primula or begonia plants. Conidia were cylindric to doliform, $31-51 \times 14-20$ $\mu \mathrm{m}$, formed singly on conidiophores erected on aerial mycelium. Base of the conidiophores were almost straight but sometimes slightly curved. Lobed appressoria differentiated on germ tubes from conidia. No. cleistothecium was observed. On the basis of the conidial stage, the fungus was identified as an Oidium sp. of the Erysiphe polygoni type.
\end{abstract}

Key words : cyclamen, Cyclamen persicum, powdery mildew, Oidium sp.

シクラメン (Cyclamen persicum Mill.) は, サクラソウ 科の多年草で, わが国で最も栽培の盛んな鉢花用花きであ る。1997 年 10 月長野県で栽培されているシクラメンの花 弁に, 白粉状の菌叢を生じるうどんこ病が発生した。本病 原菌の接種試験，形態観察等を実施したので報告する。

病徵 長野県軽井沢町の温室で栽培しているシクラメン (品種パステルストラウスとベートーベン)の花弁の表裏両 面に，花が咲きそろう 10 月中旬から白い粉状の斑点を生 じ，これがしだいに拡大して，直径 5〜10 $\mathrm{mm}$ 前後の斑点 となった。赤や紫色の花弁は白い菌叢とその上に形成され た分生子でまだら状となり，商品価值が著しく低下した。 古くなると斑点部の花弁の色はやや退色するが, 花が枯死 するまで病斑は残存した。花柄や葉には病徵が認められな かつた。

接種試験 シクラメン(品種パステルストラウス), ミニ シクラメン(市販赤色系, 品種不明), エラチオールベゴニ ア(品種ジャネット), プリムラ・ポリアンサ（品種ジュリ アン）およびプリムラ・オブコニカ（市販桃色系, 品種不 明）に対して本菌株の分生子を葉や花の上から振りかけて 接種し, $15 \sim 25^{\circ} \mathrm{C}$ 温室内で 20 日間管理した後に病徵発生 の有無を調査した。その結果, シクラメンでは花弁のみに 発病が認められ, 葉あるいは葉柄や花柄には発病がみられ ず，エラチオールベゴニアや 2 種のプリムラでは全く発病
しなかった（Table 1)。

病原菌の形態 花弁の表面上に病原菌の菌系, 分生子柄 および分生子が観察された。栽培地において本病菌の閉子 のう殼は確認できず，分生子世代のみが認められた。菌系 は, 花弁の表皮上に分岐しながら表生し, 幅 $5 \sim 9 \mu \mathrm{m}$ で, そのところどころに幅約 $7 \mu \mathrm{m}$ で比較的単純なこぶし状の 付着器と分生子柄を形成した。分生子柄は表生の菌糸から ほぼ垂直に分岐し，基部はほぼ直線状であるが，わずかに 湾曲するものもあった。Foot-cell は，全長にわたりほぼ同 幅で約 7 $10 \mu \mathrm{m}$, 長さ $32 \sim 61 \mu \mathrm{m}$ (平均 $44.9 \mu \mathrm{m}$ )。分生 子柄は通常 $2 \sim 3$ 細胞, 時に 4 細胞からなり, 長さ $67 \sim 141$ $\mu \mathrm{m}$ (平均 $108.4 \mu \mathrm{m}$ ) であった（Table 2)。

分生子は分生子柄の先端に単生するが，時に連なった状 態で観察された。無色または帯淡黄色，単胞で，表面が粗 く, 円筒形またはビア樽形, 内部にフィブロシン体は観察 されず，多数の液胞および顆粒状内容物を有した。大きさ は 31〜 $51 \times 14 \sim 20 \mu \mathrm{m}$ (平均 $44.8 \times 17.9 \mu \mathrm{m}$ ) であった (Table 2)。

また, 平田 ${ }^{6)}$ の方法に準じて発芽管の形態を観察した結 果, 本病菌は分生子の端部から発芽し, 発芽管の先端部に こぶし状の付着器を形成する場合と, 長い発芽管の先にわ ずかに膨らんだ単純な付着器を形成する場合とがあった。 それらはいずれも, 平田 ${ }^{6)}$ の述べたE. polygoni 型の形態と

* 野菜・茶業試験場 National Research Institute of Vegetables, Ornamental Plants and Tea, Ano-cho, Age-gun, Mie 5142392, Japan

** 長野県野菜花き試験場Ｎagano Vegetable and Ornamental Crops Experiment Station, Matsushiro, Nagano 381-1211, Japan 
判断された。発芽管の長さは，こぶし状の付着器を形成す る場合では約 $15 \mu \mathrm{m}$ で, 長い発芽管は $50 \mu \mathrm{m}$ 以上であっ た。

病原菌の所属および病名 シクラメン属を含むサクラソ ウ科に外部寄生するうどんこ病菌として, Braun ${ }^{11}$ は, 全世 界に分布し著しく多数の植物に宿主範囲を持つErysiphe orontii Cast. emend. Braun と，ヨーロッパでプリムラ・ オブコニカ (Primula obconica) に寄生する Oidium primulae-obconicae Cioan \& Calnegruのほか, 1939 年才 ーストリアのシクラメン上で記載された Oidium cyclaminis Wenzl ${ }^{11)}$ を掲載している。また米国の病原菌名 のリストには, シクラメンに O. cyclaminis が3), Primula

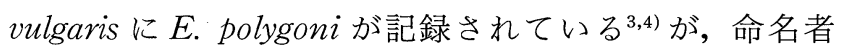
名や菌の形態の記載はない。ところでE. orontii は, Hummerlund ${ }^{5)}$ が接種試験によって多くの植物に寄生性を

Table 1. Pathogenicity of cyclamen powdery mildew isolate on various plants

\begin{tabular}{|c|c|c|}
\hline \multicolumn{2}{|c|}{ Species and cultivar inoculated } & \multirow{2}{*}{$\frac{\text { Pathogenicity }}{+}$} \\
\hline Cyclamen persicum & cv. Pastel Strauss & \\
\hline C. sp. & miniature type & + \\
\hline Begonia hiemalis & cv. Janet & - \\
\hline Primula obconica & & - \\
\hline P. $\times$ polyantha & cv. Julian & - \\
\hline
\end{tabular}

持つとして命名した E. polyphaga が植物命名規約を満た すものではなかったために Braun $^{11}$ によって採用された種 名である。したがって, Hummerlund ${ }^{5)}$ が E. polyphagaに 含めた O. cyclaminis も E. orontii に含められた1。しか し, その後, Braun ${ }^{21}$ は, O. cyclaminis を疑問種とし, シ クラメンうどんこ病菌の病原性が宿主特異的であるとの報 告があることを述べて, 本病菌の生物学的, 形態学的研究 が早急に必要であるとした。

そこで, 本報では, Braun ${ }^{1)}$ の収載したE. orontii，O. primulae-obconicae および O. cyclaminis と長野県産の菌 株を比較した (Table 2)。本菌は, O. primulae-obconicae とは分生子が単生し, フィブロシン体がないことで, $E$. orontii とは分生子が若干大きく, 単生することで区別され るが，O. cyclaminis とは分生子の大きさがほぼ一致した。 また, 接種試験の結果は本菌の宿主範囲が狭いことを示し, O. cyclaminis と同一である可能性を強く示唆している。し かし, O. cyclaminis の原記載はごく簡単でラテン記載もな いため, これだけで同定するのは困難である。そこで, こ こでは属の同定にとどめることとしたい。

わが国では, サクラソウ科の植物では, クサレダマにう どんこ病の発生が記録されているだけであり ${ }^{10)}$, シクラメ ンに寄生するうどんこ病菌の記載はこれまでなく ${ }^{7-9)}$, 本報 が初めてである。また, 本病菌の完全世代は未だに認めら れていない。したがって，わが国に発生した本病菌は，平

Table 2. Comparison of characters of powdery mildew on cyclamen, Erysiphe orontii, Oidium primulae-obconicae and O. cyclaminis

\begin{tabular}{|c|c|c|c|c|}
\hline & $\begin{array}{l}\text { Cyclamen powdery } \\
\text { mildew Nagano isolate }\end{array}$ & Erysiphe orontii ${ }^{\mathrm{a})}$ & $\begin{array}{c}\text { Oidium } \\
\text { primulae-obconicae }^{\mathrm{a})}\end{array}$ & Oidium cyclaminis ${ }^{\text {b) }}$ \\
\hline \multicolumn{5}{|l|}{ Conidia } \\
\hline $\begin{array}{l}\text { length } \times \text { width }(\mu \mathrm{m}) \\
\quad \text { (Average) }\end{array}$ & $\begin{array}{l}31-51 \times 14-20 \\
(44.8 \times 17.9)\end{array}$ & $\begin{array}{l}25-40 \times 15-23 \\
(47.6 \times 16.1)\end{array}$ & $19.04-52.36 \times 11.9-24.99$ & $30-50 \times(11-) 13-18(-20)$ \\
\hline shape & $\begin{array}{l}\text { cylindric to } \\
\text { doliform }\end{array}$ & $\begin{array}{l}\text { ellipsoid-ovoid to } \\
\text { doliform-subcylindric }\end{array}$ & $\begin{array}{l}\text { ellipsoid-doriform to } \\
\text { cylindric }\end{array}$ & ellipsoid \\
\hline formation & singly & in chain & in chain & $\mathrm{n}^{\mathrm{c})}$ \\
\hline fibrosin bodies & none & none & present & $\mathrm{n}$ \\
\hline \multicolumn{5}{|l|}{ Conidiophores } \\
\hline No. of cells & $2-3(-4)$ & (3) & $\mathrm{n}$ & $\mathrm{n}$ \\
\hline length $(\mu \mathrm{m})$ & $67-141(108.4)$ & & $\mathrm{n}$ & $\mathrm{n}$ \\
\hline erection & straight/often curved & straight/often curved & $\mathrm{n}$ & $\mathrm{n}$ \\
\hline foot-cell & cylindric & cylindric & $\mathrm{n}$ & $\mathrm{n}$ \\
\hline length $\times$ width $(\mu \mathrm{m})$ & $32-61 \times 7-10$ & $40-100 \times 10-13$ & $\mathrm{n}$ & $\mathrm{n}$ \\
\hline Appressoria & lobed & nipple-shaped & $\mathrm{n}$ & $\mathrm{n}$ \\
\hline Cleistothecia & absent & gregarious & absent & absent \\
\hline $\operatorname{size}(\mu \mathrm{m})$ & & 80-140 & & \\
\hline No. of asci & & $5-14$ & & \\
\hline $\operatorname{asci}(\mu \mathrm{m})$ & & $45-75 \times 25-40$ & & \\
\hline No. of ascospores & & $2(-4)$ & & \\
\hline $\operatorname{ascospores}(\mu \mathrm{m})$ & & $16-25 \times 12-15(-17)$ & & \\
\hline Host species & Cyclamen persicum & $\begin{array}{l}\text { Cyclamen persicum } \\
\text { numerous host species }\end{array}$ & Primula obconicae & Cyclamen persicum \\
\hline
\end{tabular}

a) Braun ${ }^{1)}$, b) Wenzl ${ }^{11}$, c) not determined or not mentioned. 
田6) E. polygoni 型に属する Oidium sp.とし, 本病をシク ラメンうどんこ病 (powdery mildew of cyclamen) と呼 ぶことを提案する。

本報告を草するにあたり，文献調査にご協力いただいた 東京農業大学小林享夫教授ならびに三重大学生物資源学部 高松 進助教授に深謝する。

\section{引用文献}

1. Braun, U. (1987). A monograph of the Erysiphales (powdery mildews). Nova Hedwigia Beih. 89: 1-700.

2. Braun, U. (1995). The Powdery Mildews (Erysiphales) of Europe, Gustav Fischer Verlag, Jena, p. 230.

3. Daughtrey, M.L., Wick, R.L. and Peterson, J.L. (1995). Compendium of Flowering Potted Plant Diseases, APS Press, St. Paul, Minnesota, p. 40.

4. Faar, D.F., Bills, G.F., Chamuris, G.P. and Rossman,
A.Y. (1989). Fungi on plants and plant products in the United States, APS Press, St. Paul, Minnesota, p. 444.

5. Hammerlund, C. (1945). Beitrage zur Revision einiger imperfekten Mehltau-Arten. Erysiphe polyphaga nov. sp. Bot. Not. 1945 : 1-126.

6. 平田幸治 (1955). 白渋病菌の分生胞子の発芽管に就いて (第 2 報)。新潟農林研究 $7: 24-36$.

7. 日本植物病理学会編 (1993). 日本有用植物病名目録, 第 2 巻, 第 3 版, 日本植物病理学会, 東京, pp. 108-109.

8. 野村幸彦(1997)。 日本産ウドンコ菌科の分類学的研究, 養 賢堂, 東京.

9. 大谷吉雄 (1988). 伊藤誠哉 日本菌類誌, 第 3 巻, 子のう 菌類, 第 2 号, 養賢堂, 東京, p. 310.

10. 和田久美子・平田幸治 (1970)。 日本のうどんこ病菌とその 寄主植物。新潟大農研報 $29: 77-114$.

11. Wenzl, H. (1939). Echter Mehltau auf Cyclamen persicum. Z. Pflanzenkr. 49 : 566-567.

(平成 10 年 1 月 23 日受付；平成 10 年 7 月 15 日受理) 


\section{Plate I}
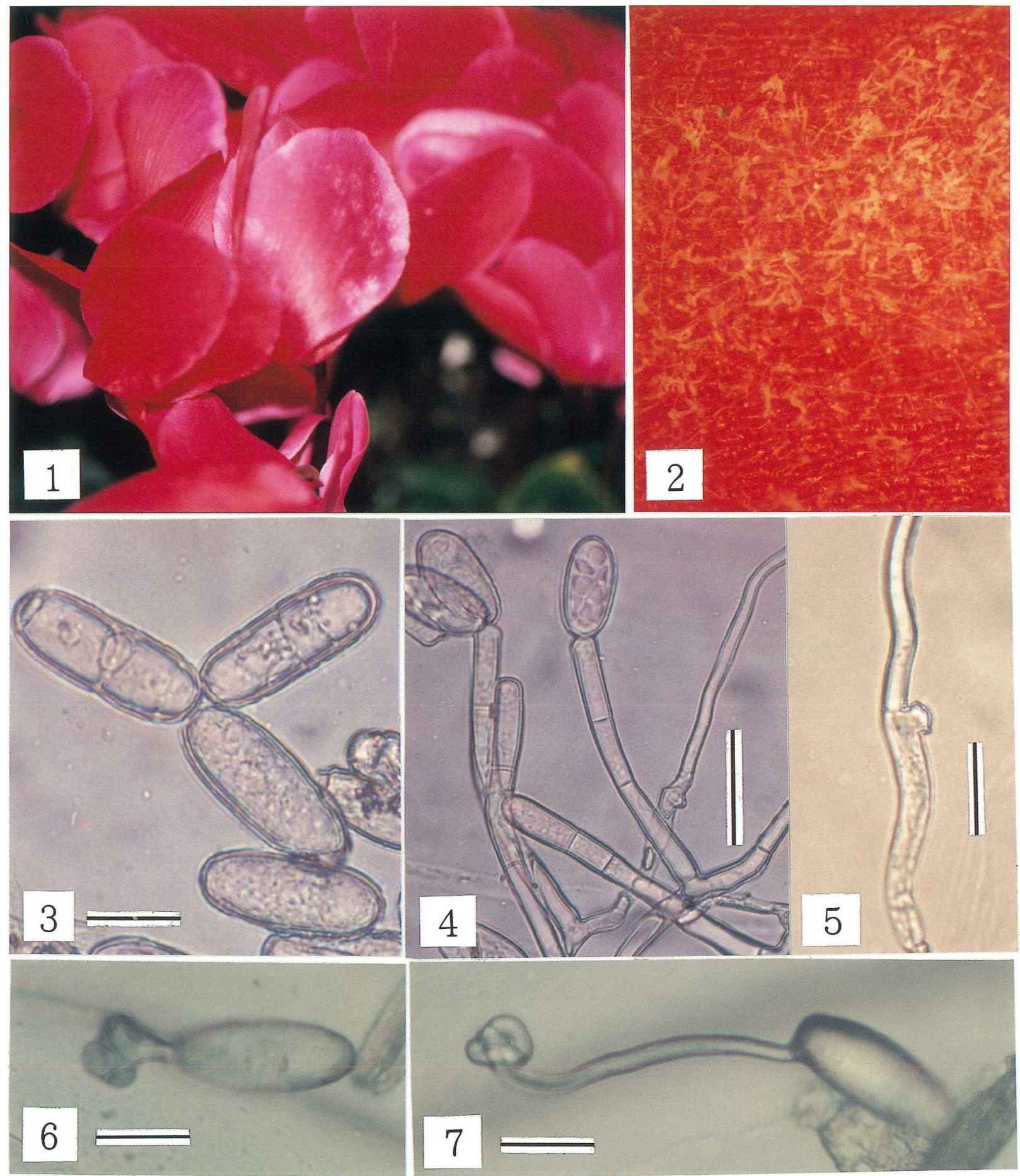

Plate I

1. White powdery patches appeared on the red- or purple-colored petals of the cyclamen plant in Nagano prefecture.

2. White mycelia and conidia on the surface of the petal.

3. Cylindric to doliform conidia. [Scale: $20 \mu \mathrm{m}$ ]

4. Conidium on conidiophore erected on superficial mycelium. [Scale : $50 \mu \mathrm{m}$ ]

5. Slightly developed, lobed-shaped appressorium on the mycelium. [Scale: $20 \mu \mathrm{m}$ ]

6. Lobed appressorium on the germ tube. [Scale : $20 \mu \mathrm{m}$ ]

7. Germinated conidium with simple germ tube. [Scale: $20 \mu \mathrm{m}$ ] 